Working Paper 02-32

Economics Series 13

February 2003
Departamento de Economía

Universidad Carlos III de Madrid

Calle Madrid, 126

28903 Getafe (Spain)

Fax (34) 916249875

\title{
SPILLOVERS IN PRODUCT AND PROCESS INNOVATION: EVIDENCE FROM MANUFACTURING FIRMS *
}

\author{
Carmine Ornaghi ${ }^{1}$
}

\section{Abstract}

This paper proposes a new empirical approach to assess the impact of knowledge spillovers on firms' productivity and demand. I consider a model where process innovations spillovers to other firms raise firms relative efficiency and technological diffusion of product innovations enhances firms' demand. By modelling knowledge capital as a function of own investment in $\mathrm{R} \backslash \& \mathrm{D}$ and spillovers, I can compare the impact of these two complementary sources of knowledge on both the supply and the demand side. The results obtained confirm the findings already highlighted by previous empirical studies that technological externalities affect significantly firms' productivity growth. The new result obtained is that technological diffusion of product innovations is larger than the one deriving from process innovations, both in magnitude and pervasiveness.

Keywords: Innovation; Knowledge capital; Spillovers.

JEL Classification: L61, O30.

\footnotetext{
${ }^{1}$ Departamento de Economía, Universidad Carlos III de Madrid. E.mail: carmine@eco.uc3m.es
}

\footnotetext{
* I wish to thank Jordi Jaumandreu and Pedro Marin for many helpful discussions and suggestions. I benefit from comments from Bronwyn Hall, Matilde Machado, Georges Siotis and participants in seminars at Universidad Carlos III de Madrid and University of California at Berkeley.
} 


\section{Introduction}

Since the seminal paper of Griliches (1979) on the productivity effect of R\&D, several economists have investigated the relationship between firms' innovation and productivity growth. The first studies aimed at assessing the importance of research in explaining productivity improvements relied on inserting another type of capital, computed from data on R\&D expenditure, to the list of inputs entering the production function. But economists have soon realized that this type of capital (generally defined knowledge capital) does not depend only on firms own investments in $\mathrm{R} \& \mathrm{D}$. The non-rival character of knowledge implies that a firm may learn from other firms' innovations, whenever the technological contents of their R\&D activities are not successfully confined inside their walls. Thus, the firm's productivity also depends on the pool of general knowledge it has access to. This is what is known as technological externalities or spillovers. By including a proxy for this variable in the firm production function, it is possible to determine whether spillovers play an important role in generating productivity growth. ${ }^{1}$ The economy, as a whole, would be enriched with such a positive externality since it represents a source of increasing social returns.

The common feature of all these studies is that technological innovation is assumed to be process oriented: the knowledge capital acquired by a firm improves the mechanism by which input is transformed into output. But this approach ignores another important dimension of innovation: improvements in the quality of existing products and the introduction of new goods. Studying the impact of spillovers only on the supply or productivity side can show only part of the picture. A firm that enhances the quality of its products by learning the technological innovations introduced by competitors is receiving a positive externality that can be estimated only shifting the attention to the demand or consumption side. ${ }^{2}$ Moreover, consider that the channels of

\footnotetext{
${ }^{1}$ There is a large literature that deals with the empirical estimation of spillovers in the framework of productivity analysis. Griliches (1992) and Nadiri (1993) offer extensive surveys of the main contributions. Although the magnitude of spillover seems to vary largely between industries and countries, the relevance of technology spillovers is not questioned. See Los and Verspagen (2000) for a recent study.

${ }^{2}$ Mansfield, Rapport, Romeo and Wagner (1977) conduct a number of case-studies to estimate social and private rate of return from investments in product and process innovation. Moreover, several papers have used this distinction to get interesting insights
} 
technology spillovers are hardly the same. Imitation of a product innovation can be simply achieved through reverse engineering while diffusion of process innovation may require more sophisticated channels, such as industrial espionage or recruitment of engineers and experts of rival firms. Therefore, the magnitude and pervasiveness of spillovers for product and process $R \& D$ are likely to be different. Although both of them can possibly lead to an increase in the output produced by the firm, the forces behind this output expansion are quite different and deserve a separate analysis.

This paper proposes an original empirical approach to the problem of assessing the impact of knowledge spillovers on firms' productivity and demand. I consider a model where process innovations spillovers to other firms raise firms relative efficiency and technological diffusion of product innovations enhances firms' demand. To the best of my knowledge, there are no similar studies in the empirical literature on spillovers. By modelling knowledge capital as a function of own investment in R\&D and spillovers, I can compare the impact of these two complementary sources of knowledge on both the supply and the demand side. The results obtained confirm the findings already highlighted by previous empirical studies that technological externalities affect significantly firms' productivity growth. The new insight presented is that the magnitude and pervasiveness of spillovers from product innovation are larger than those coming from process innovation. ${ }^{3}$

The data base used in this paper reports detailed information on firms' individual input, R\&D expenditure, types of innovation achieved as well as observations on output price changes and other demand-related variables, which is a rather unusual feature. This allows me not only to specify the richer framework explained above but also to introduce new features in defining the knowledge capital that can partially overcome the problems usually found in the empirical literature. By employing the available information on type and timing of innovations, I can model the transformation of research

in related areas. Mansfield (1983), for example, surveys the major product and process innovations in the chemical, drug, petroleum, and steel industries to shed some light on the effects of technological change on market structure. Levin and Reiss (1988) define a theoretical framework to analyse the tradeoffs that firms face between imperfectly appropriable product and process innovation, when underlying technological opportunities differ.

${ }^{3}$ A similar framework is used in Garcia, Jaumandreu and Rodriguez (2002) to study the elasticity of employment with respect to innovations. 
into productivity gains and product quality improvements. The resulting measure of internal R\&D can then be considered a better proxy for innovation output. As discussed below, this refinement leads to a relevant increase in the point estimate of $\mathrm{R} \& \mathrm{D}$ capital coefficients for both the production function and the demand equation. As far as the spillover variable is concerned, I generalize previous characterisations of the potential spillover pool, constructing different measures of proximity according to basic firm's characteristics, such as the number of employees or the localization. This approach can be considered an alternative to the one defined by Jaffe (1986) using firm data on the distribution of patents, ${ }^{4}$ as it allows to refine the measure of spillovers without relying on detailed patenting data (that are generally not available). The results obtained suggest that size is a main determinant of the magnitude and extent of technology dissemination.

The nature of this study requires the analysis of a large sample of markets. To the extent that technological innovations can be applied to several manufacturing sectors, a cross-sectional approach seems an objective way to get useful stylized facts on the magnitude of spillovers in industrialized countries. This paper is based on an unbalanced panel data of Spanish manufacturing firms that includes more than 2,000 entities during the period 1990-1999. The surveyed sample is made up of firms performing and not performing $R \& D$ activities respecting the population proportions.

The article is organized as follows. Section 2 provides the econometric framework used to estimate the magnitude of spillovers for the production function and the demand equation. Section 3 presents the data set and the specification of the knowledge variables. Empirical results are summarized in Section 4. Some final comments are presented in the concluding section.

\footnotetext{
${ }^{4}$ Using data on the distribution of patents, Jaffe (1986) first defines the "technological position" of a firm's research program and then he constructs a measure of proximity among firms according to the correlation of their "technological position vector". He assumes that the closer are two firms in their research program, the higher is the fraction of R\&D capital that can leak out.
} 


\section{Modelling Spillovers in Product and Process R\&D}

In this section, I discuss the details of the econometric framework that is used to estimate the impact of spillovers on production and demand. Assume that the output of firm $i$ in period $t, Y_{i t}^{p}$, is produced from three "conventional" inputs, labour $L_{i t}$, materials $M_{i t}$ and physical capital $C_{i t}$ and also depends on a technological parameter $A$, which in turn is a function of the industry $j$ 's specific rate of disembodied technical change, $\lambda_{j t}$, the individual research effort of the firm, $R_{i t}$, and the knowledge spillovers, $S_{i t}$. In order to control for short term adjustments associated with the business cycle, the degree of capacity utilization, $U$, is added as a further explanatory variable in the production function.. ${ }^{5}$ According to this explanation, the firm production function takes the form:

$$
Y_{i t}^{p}=A\left(\lambda_{j t}, R_{i t}, S_{i t}\right) F\left(L_{i t}, M_{i t}, C_{i t}, U_{i t}\right)
$$

Now assume that the demand equation can be written as:

$$
Y_{i t}^{g}=D\left(P_{i t}, A D_{i t}, R_{i t}, S_{i t}, Z_{-i t}\right)
$$

where $Y_{i t}^{g}$ is the quantity demanded, $P_{i t}$ refers to price, and $A D_{i t}$ stands for advertising. Again, the knowledge capital of a firm is made up of the individual research effort $R_{i t}$ and the spillover pool $S_{i t}$. The latter variable is meant to measure the effect on demand of any product quality improvements achieved by learning the technological innovation first introduced by a competitor. Finally, $Z_{-i}$ is a vector of prices, knowledge capital and advertising for rivals.

Equation (2) adapts to a model of vertical differentiation where both knowledge capital and advertising will affect the demand through an im-

\footnotetext{
${ }^{5}$ The production function is defined as a relation between flow of output and inputs. While annual price and quantity data are generally available for labour and materials, physical capital $C$ is usually computed as a stock using the perpetual inventory method. As noted by Hulten (2000), this approach is valid only as long a flow of services from capital are proportional to the stock. But proportionality is not always a realistic assumption, in particular during period of low demand characterized by low capital utilization. This topic is investigated in a companion paper, Ornaghi (2002).
} 
provement of real and perceived product quality, respectively. ${ }^{6}$ Notice that the demand enhancing effect of knowledge capital can materialise via two different mechanisms: a market expansion effect and a business stealing effect. In the first case the introduction of new products, by attracting new consumers to the market, can benefit the pioneer firm and all the firms that successfully adopt the innovation without necessarily affecting less innovative firms. In a context where market expansion effects are minimum compared to business stealing effect, some firms will expand their activities in detriment of their competitors. In both cases, it is likely that only some firms will be able to reproduce the innovation achieved by competitors, depending on their characteristics. Results presented in Section 4 suggest that size is a main determinant of a firm's capacity of learning from rivals.

The possible positive impact on a firm demand schedule of other firms' investments in product improvements is likely to depend on the way markets are classified. If we define an industry broadly enough to consider vertical relations or complementary products, then it is evident that a firm's product innovation may have a positive effect on other firms' demand. ${ }^{7}$ It is then an interesting exercise to assess whether any difference in the magnitude between spillovers for product and process R\&D tends to change with alternative classification of the industries making up the manufacturing sector. The results obtained suggest that technological externalities associated to product innovations have a broader impact: firms can take advantage of product improvements introduced by firms in not strictly related markets. On the other hand, spillovers from process innovations are limited to narrowly defined industries.

Following the approach used by Klette (1996 and 1999), the production function can be expressed in terms of logarithmic deviations from a reference input-output vector (e.g., $Y_{o t}^{p}, L_{o t}, M_{o t}, .$. ). This point of reference can be thought of as the representative firm that each firm within an industry has to compete with. In the empirical application, I have characterised this

\footnotetext{
${ }^{6}$ The demand equation might depend on other elements, such as brand image or custumers' loyalty. As explained below, estimation in first-differences are not affected as long as these omitted elements are constant over time.

${ }^{7}$ Consider the case of the computer industry. Usually the introduction of a new data processor has a demand expanding effect for producer of computer equipment and software. Moreover, this can expand the sales of complementary products such as scanners, printers and multimedia apparatus.
} 
reference point as the average values of output and inputs within the 3-digit CNAE code industry in each year. ${ }^{8}$ The use of a year-specific industry mean value eliminates the technical change, $\lambda_{j}$, from specification (1). It follows that there is no need to introduce time-dummies in the estimation. This normalisation has the additional advantage of refining the model from omitted factors that are common to all the firms within a (3-digit CNAE) industry, thus attenuating the problem of great heterogeneity associated to crossindustry studies. In the same way, the demand equation can be expressed using a log-linear expansion around the reference firm (e.g., $\left.Y_{o t}^{d}, P_{o t}, A D_{o t}, ..\right)$. Although estimation of the demand relationship would require complete information on rivals' prices and other relevant variables, this transformation allows us to consider the effect of an average change in rival's prices, knowledge capital and advertising expenditure on the quantity demanded. ${ }^{9}$

Rewriting equation (1) and (2), in terms of logarithmic deviations from the representative firm, we obtain:

$$
\hat{y}_{i t}^{p}=\alpha_{1} \hat{l}_{i t}+\alpha_{2} \hat{m}_{i t}+\alpha_{3} \hat{c}_{i t}+\alpha_{4} \hat{u}_{i t}+\alpha_{5} \hat{r}_{i t}+\alpha_{6} \hat{s}_{i t}+\hat{\varepsilon}_{i t}
$$

and

$$
y_{i t}^{g}=\beta_{1} \widehat{p}_{i t}+\beta_{2} \widehat{a d}_{i t}+\beta_{3} \widehat{r}_{i t}+\beta_{4} \hat{s}_{i t}+\hat{\zeta}_{i t}
$$

where lowercase letters with a hat stand for logarithm deviations from the point of reference of their upper-case counterparts, e.g. $\hat{y}_{i t}^{p}=\ln \left(Y_{i t}^{p} / Y_{o t}^{p}\right)$; $\hat{\varepsilon}_{i t}$ is the random error term for the production function, representing the effect of efficiency differences, functional form discrepancies and measurement errors while $\hat{\zeta}_{i t}$ is the error component capturing stochastic shocks to the demand.

There are two relevant econometric issues that have to be carefully considered at this point. Firstly, one of the most important components of $\varepsilon$ in the production function is likely to be due to firm-specific factors of production, such as entrepreneurial ability, that are not observable. This component determines productivity differences between firms that tend to

\footnotetext{
${ }^{8}$ The CNAE classification embraces about 120 different manufacturing sectors. This classification is similar to the 3-digit ISIC in terms of market definition.

${ }^{9}$ Normalizing the demand equation with respect to the reference firm, we can also eliminate any market dynamism (e.g. market expansion or recession) that is common to all the firms in the industry. Kettle (1996) uses a similar approach to model the demand equation.
} 
be rather persistent over time. We can consequently decompose the error term as:

$$
\varepsilon_{i t}=\mu_{i}+v_{i t}
$$

where $\mu_{i}$ is the just mentioned fixed-effect that account for the permanent heterogeneity across firms whereas $v$ includes temporary productivity shocks and measurement errors. To the extent that $\mu_{i}$ affects the current input choice decisions, the assumption of no correlation between the included regressors and the disturbance term does not hold and this prevents us from using Ordinary Least Square (OLS) estimation. The persistency of high autocorrelation of the errors in the $O L S$ estimation (in levels) suggests that unobserved heterogeneity is a relevant issue that must not be undervalued. ${ }^{10}$ Therefore, we estimate equation (3) in "first differences" in order to eliminate the term $\mu_{i}$ from the specification of the production function:

$$
\tilde{y}_{i t}^{p}=\alpha_{1} \tilde{l}_{i t}+\alpha_{2} \tilde{m}_{i t}+\alpha_{3} \tilde{c}_{i t}+\alpha_{4} \tilde{u}_{i t}+\alpha_{5} \tilde{r}_{i t}+\alpha_{6} \tilde{s}_{i t}+\tilde{v}_{i t}
$$

where lower case letters with tilde represent log differences of the variables normalized with respect to the representative firm, that is $\tilde{y}_{i t}^{p}=\ln \left(Y_{i t}^{p} / Y_{o t}^{p}\right)-$ $\ln \left(Y_{i t-1}^{p} / Y_{o t-1}^{p}\right)$.

In the same way, there are some (omitted) elements, such as the brand image or the consumers' loyalty, buried in the residual of the demand equation that are presumably constant over time. By taking first differences to eliminate these omitted variables, we obtain the estimating equation:

$$
\tilde{y}_{i t}^{g}=\beta_{1} \widetilde{p}_{i t}+\beta_{2} \widetilde{a d}_{i t}+\beta_{3} \widetilde{r}_{i t}+\beta_{4} \widetilde{s}_{i t}+\hat{\vartheta}_{i t}
$$

Secondly, consistent estimation of equation $(\mathrm{P})$ and $(\mathrm{G})$ by $O L S$ requires predeterminacy of the regressors. As far as the production function is concerned, whenever a productivity shock is anticipated before the optimal quantity of inputs is chosen, disturbances $\tilde{v}_{i t}$ are transmitted to the decision equation of the inputs. This means that there is a positive correlation between the right-hand variables and the error term, thereby invalidating the use of $O L S$ estimation. This delicate econometric issue is known in the literature

\footnotetext{
${ }^{10}$ This evidence is confirmed by the results of the Hausman test, which rejects the null hypothesis that the "random effect" estimates are not statistically different from the one based on the "fixed effect" model. See Greene (1997) for further details.
} 
as the simultaneity problem. ${ }^{11}$ Among the three standard input variables of equation $(\mathrm{P})$, labour, $L$, is the one more likely to be correlated with the error term. Besides, using the Sargan difference test, the null hypothesis of exogeneity of the capacity utilization term is rejected. We then use past values of labour and capacity utilization to instrument these two endogenous variables. A similar issue needs to be considered for the demand relationship: the simultaneity between price and quantity demanded. As shown in a standard downward-sloping demand curve, when the price increases, the quantity demanded falls. At the same time, quantity affects the price thought the supply curve whenever the latter is not horizontal (infinite price elasticities). This implies that an unobservable exogenous demand shock can affect not only purchases but also prices. The latter are then endogenous variables and $O L S$ regression does not give consistent estimation of the parameters defined in equation $(\mathrm{G})$. The use of panel data provides a solution to this problem since we can use lags of this endogenous variable as instruments. I shall come back on this point in Section 4

\section{Data and Variables}

The data used in this study are retrieved from the Encuesta sobre Estrategias Empresariales, ESEE, (Business Strategy Survey) an unbalanced panel sample of Spanish manufacturing firms published by the Fundación Empresa Pública covering the period 1990-1999. The raw dataset consists of 3,151 firms for a total number of 18,680 observations. A "clean" sample is defined according to a set of criteria which are given in Appendix A. Briefly, I require value added be positive and I trim outliers in growth rates. ${ }^{12}$ The sample employed here consists of all the firms that have been surveyed for at least three years after dropping all the time observations for which the data required to the estimation are not available. ${ }^{13}$ It can be considered approx-

\footnotetext{
${ }^{11}$ See Griliches and Mairess (1995), for a detail explanation of the simultaneity bias.

${ }^{12}$ Only 424 observations are removed applying these criteria. Their main effect is to increase the point estimate of the coefficient of internal $R \& D$ capital and to reduce the second order autocorrelation among observations.

${ }^{13}$ Estimations has been run also using the balanced panel sample (firms with all the 10 years observations). The results obtained do not differ sensibly from the one reported in Section 4.
} 
imately representative of the manufacturing sector, and hence inference can be regarded as globally valid.

The ESEE provides detailed data on firms' output, standard inputs, R\&D expenditures and innovation. Differently from other data set, a crucial feature of this survey is that it includes observations on firms' price changes and other demand related variables, such as advertising. This allows us to define and estimate the demand equation $(\mathrm{G})$ defined above. The surveyed sample includes, approximately in population proportion, firms performing and non-performing R\&D activities. Detailed information on the distribution of $\mathrm{R} \& \mathrm{D}$ performers among different size-classes are reported in Appendix A.

\subsection{On Knowledge Capital and other Variables}

This section deals with the construction of the two components of a firm's knowledge capital, namely, individual research effort (R) and spillover pool (S). At the end of the section, we also address some other issues concerning the construction of other variables. A complete explanation of all the variables used in the demand and production equations, together with descriptive statistics, can be found in Appendix A.

To define the amount of knowledge produced by internal research activities, I follow the perpetual inventory method like that commonly used for physical capital. ${ }^{14}$ The equation defining the internal R\&D capital is the following:

$$
R_{i t}^{*}=(1-\rho) R_{i t-1}^{*}+I_{i t-1}
$$

where $R_{i t}^{*}$ is the $\mathrm{R} \& \mathrm{D}$ stock in period $t, I_{i t}$ is the $\mathrm{R} \& \mathrm{D}$ expenditure during the period and $\rho$ is the depreciation rate. Investments in $R \& D$ take into account not only the cost of intramural activities but also payments for outside contracts and imported technology.

To improve the specification of the internal knowledge capital, I introduce a slight modification and assume that $R \& D$ capital becomes operative at the time that a new innovation is achieved. Thus, R\&D capital in period $t$ increases only if a new innovation has been introduced that year. The

\footnotetext{
${ }^{14}$ See Hall and Mairesse (1995) for further detail and an empirical application.
} 
assumption is made that if in period there are no innovations, past $R \& D$ expenditures do not have economic effects and the R\&D stock of the firm is still the same. This variable can then be considered a better proxy for innovation output instead of research inputs. Given that firms report the type of innovation introduced each year, we can model the transformation of research expenditures into process innovation, $R^{\text {proc }}$, and product improvements, $R^{\text {good }}$, separately. Accordingly, we obtain the following specifications:

$$
\begin{aligned}
& R_{i t}^{\text {proc }}=d p_{i t} * R_{i t}^{*}+\left(1-d p_{i t}\right) * R_{i t-1}^{\text {proc }} \\
& R_{i t}^{\text {good }}=d g_{i t} * R_{i t}^{*}+\left(1-d g_{i t}\right) * R_{i t-1}^{\text {good }}
\end{aligned}
$$

where $d p_{i t}$ and $d g_{i t}$ are dummies that take value 1 if a process innovation or a product innovation are, respectively, achieved in period $t .{ }^{15}$ Hence, productivity improvements and demand shifts are associated with the introduction of innovations of each type. At the same time, the impact of an innovation is assumed to be proportional to the $\mathrm{R} \& \mathrm{D}$ effort experienced since the introduction of the last innovation. Both variables outperform simpler measures of knowledge capital based on law of motion (6) above. ${ }^{16}$

There are two major problems when computing the internal knowledge capital. Firstly, equation (6) requires to know the complete history of R\&D expenditures since the birth of the firm. Given that the data are limited to the period 1990-1999, we need to define a plausible value of the knowledge stock for 1990. To this purpose, I use the series of R\&D expenditures during the eighties and nineties, provided by the National Institute of Statistics (Instituto Nacional de Estadistica - INE) for 18 different industries. ${ }^{17}$ Once

\footnotetext{
${ }^{15}$ See Appendix A for detailed information on the percentage of observations with "positive" process innovation $(\mathrm{dp}=1)$ and product innovation $(\mathrm{dg}=1)$ and the relative distribution among size-classes.

${ }^{16}$ The point estimate of $R^{\text {proc }}$ coefficient increases more than $20 \%$ (from around 0.08 to 0.10 ) while the one of $R^{\text {good }}$ raises more than $70 \%$ (from around 0.14 to 0.25 ).

${ }^{17}$ The definition of the initial capital does not seem to be a relevant issue in the case of Spain, considering that the level of R\&D investments during the seventies is negligible and the expenditures during the eighties are sensibly lower than those of the following decade. Total R\&D investments amount to 282 millions of euros in 1982 compared to 1,483 in 1990. The average amount of R\&D expenditures for the period 1982-1989 is 599 millions compared to a higher 1,581 for 1990-1992. We have computed alternative initial values for the $R \& D$ capital and results are not sensibly different from the one presented in Section 4 .
} 
computed the firms' average expenditures during the period 1990-1999 and the associated expenditure at industry level, we assume that the individual $R \& D$ efforts follow the same evolution of total industry investments for each year since the firm has been established (if the firm has been established before 1980, we just consider the expenditure during the eighties). ${ }^{18}$

Secondly, it is necessary to define a value for the depreciation rate. As pointed out by Pakes and Schankerman (1984), the depreciation of an innovation is not due to a decay in the productivity of knowledge but rather from the fact that competitors can partly or entirely displace this innovation by either reproducing it or developing their-own innovations. Given that knowledge capital in normalized with respect to the reference firm, the values $R^{\text {proc }}$ and $R^{\text {good }}$ decrease whenever one of the competing firms introduce a process or product innovation. This means that an important source of depreciation of firms' knowledge capital is already considered. Therefore, I decide to use a depreciation rate of zero $(\rho=0) .{ }^{19}$ As discussed at length in Appendix $\mathrm{B}$, the so computed $\mathrm{R} \& \mathrm{D}$ capital variable is assumed not to be affected by (relevant) measurement errors.

In my dataset a large number of firms report no R\&D. The log of the variable $R$ is then undefined and this causes the estimation to collapse. As other authors ${ }^{20} \mathrm{I}$ address this problem by setting the value of the variable equal to 1 before normalising it with respect to the reference firm. The implicit assumption behind this transformation is that all firms produce some new knowledge, although this is not necessary the output of formal R\&D investments.

The potential spillover pool, $S$, is constructed using a weighted sum of the other firms' R\&D capital, with weights " $w$ " defined by a certain measure of proximity between firms. Thus, we can write:

\footnotetext{
${ }^{18}$ For example, suppose that firm $i$ average expenditure during the period 1990-1999 amounts to $5 \%$ of total industry $j$ average expenditure for the same period. We define firm $i$ investments for the previous decade applying this percentage to total industry $j$ $R \& D$ investments as reported by the INE.

${ }^{19}$ We have tested for the robustness of our results using a depreciation rate of 0.15 and 1. We have found that results reported in Section 4 are substantially confirmed using these two alternative values of $\rho$. In particular, while internal R\&D capital has a lower impact on firms' productivity and demand when we use $\rho=1$, the spillover variables are more stable across these alternative specifications.

${ }^{20}$ See Kettle (1996).
} 


$$
S_{i}=\sum_{j \neq i} R_{j} * w_{i j}
$$

where $w_{i j}$ denotes the weight assigned to firm $j$ 's $R \& D$ stock in the spillover pools available to firm $i$.

The simplest way to compute the spillover pool is to assume that the distance between two firms depends only on the industrial proximity: spillovers are then the unweighted sum of the R\&D stocks for all other firms within the same industrial sector. ${ }^{21}$ We label the resulting pairs of spillover variables $S 53_{\text {basic }}^{\text {proc }}$ and $S 53_{\text {basic }}^{\text {good }}{ }^{22}$ This specification rests on the strong assumption that firms have the same chance of borrowing knowledge from one another, which is likely not to hold. I then modify this approach by taking into account the size of the firms. Standard oligopolistic models show that more efficient firms have larger market shares. At the same time models of (vertical) product differentiation suggest that the higher is the quality of the product, the larger is the market share retained by the firm producing that product. In the context of Research Joint Venture, Cassiman and Veugelers (1999) and Hernan, Marin and Siotis (2003) suggest that size is likely to be highly correlated with the "absorptive capacity" of the knowledge pool generated inside the joint venture. This suggests that size is naturally linked to the firms' stock of knowledge capital and it can probably play a fundamental role in defining the absorptive capacity of firms. Our dataset divides firms in six groups depending on the number of employees. ${ }^{23}$ To define the spillover pool of firm $i$, we sum separately the R\&D capital of all the firms in the same industry (as defined by the 53-sector classification) that fall in the same size-group and

\footnotetext{
${ }^{21}$ To this porpuse, I have grouped the 120 sectors defined by the 3 -digit CNAE code (see footnote 15) into 53 and 18 industries. The latter is a standard industrial classfication, similar to the 2-digit ISIC. The 53-sector classification derives from a compromise between a finer market definition (that is likely to be an important requisit for the correct assessment of spillover effects) with the scarsity of observations that a too fine classification would imply. See Appendix D for further detail.

${ }^{22}$ Where 53 refers to the 53-sector classification used to define the industry the firm belongs to and the subscript basic means that we use the unweighted sum of R\&D capital. The superscript distinguishes between spillovers in process and product innovations, depending on the R\&D variable - $R^{\text {proc }}$ and $R^{\text {good }}$ - used in equation (8) above.

${ }^{23}$ Group 1 : 20 or less employees; group 2: between 21 and 50 employees; group 3: between 51 and 100 employees; group 4: between 101 and 200 employees; group 5: between 201 and 500 employees; group 6: more than 500 employees.
} 
then of those firms that are in each smaller and/or bigger size-group. ${ }^{24}$ Table 1 reports the results of the estimation of the resulting 11 spillover variables (see footnote 24 and Appendix C) for the production function (column 1) and the demand equation (column 2). ${ }^{25}$

\section{INSERT TABLE 1.1 ABOUT HERE}

The general pattern that emerges from these figures is that firms can benefit from the R\&D efforts undertaken by firms of the same size and, even to a greater extent, by firms with a lower number of employees. At the same time, firms can hardly take advantage from process or product innovations introduced by larger competitors. This interesting finding is probably due to several concomitant reasons. First, it is more likely that a small firm does not have the necessary financial and/or knowledge bases to adopt the innovation first introduced by a large competitors than vice versa.. Moreover, large firms have probably a higher experience in dealing with all those legal and strategic tools (e.g. patents and secrecy) aimed at protecting the technological contents of their R\&D activities. Finally, it is not uncommon that small inventors decide to sign agreements with large

\footnotetext{
${ }^{24}$ For example, if firm $i$ belongs to group 4, we define six spillover variables: the first one as the sum of the R\&D of all the firms with the same size - group 4 - that are in the same industrial sector (we labell this varible $S 53_{\text {same }}$ ), other two as the sum of R\&D stocks of all the firm in the same industrial sector that are one size-group smaller - group 3 - or bigger - group 5 - (we labell these two varibles $S 53_{\text {small } 1}$ and $S 53_{\text {big } 1}$, respectively), the next two as the sum of the R\&D capital of all the firms that are two size-group beneath - group 2 - and ahead - group 6 - (labelled $S 53_{\text {small2 }}$ and $S 53_{\text {big } 2}$ ) and finally we sum the R\&D of the firm in the same industrial sector that are in group 1 $\left(S 53_{\text {small } 3}\right)$. Correspondendly, if firm $i$ belongs to group 6 , the six spillover variables we compute are: $S 53_{\text {same }}, S 53_{\text {small } 1}, S 53_{\text {small2 }}, S 53_{\text {small } 3}, S 53_{\text {small4 }}$ and $S 53_{\text {small5 }}$ while if firm $i$ belongs to group 1 the associated variables are: $S 53_{\text {same }}, S 53_{b i g 1}, S 53_{b i g 2}, S 53_{b i g 3}$, $S 53_{\text {big }}$ and $S 53_{\text {big } 5}$. Note that when constructing these variables, we implicitly make the assumption that the impact on any firm belonging to size class $k$ of the R\&D undertaken by all competitors in size class $k+s$ (with $|s| \leq 5$ ) depends on $s$ but not on $k$ (e.g. technological spillovers from firms in group 2 to firms in group 4 are equivalent to those from firms in group 4 to firms in group 6).

${ }^{25}$ While all the results presented in this study has been estimated with $G M M$ technique, coefficients of the production function reported in Table 1.1 has been estimated with standard $O L S$ method. Compared to GMM, OLS gives similar point estimate of the several spillover variables reported in Table 1.1 but coefficients are more precisely defined.
} 
firms to commercialize their new products. This is a clear case where the product innovation achieved by a small firm has a positive impact on the demand of a large firm.

Now, results in Table 1.1 are consistent with the following null hypothesis: $^{26}$

$$
\begin{aligned}
\alpha_{1}= & \alpha_{2}=\alpha_{3} \\
\alpha_{4}= & \alpha_{5}=\alpha_{6}=2 * \alpha_{1} \\
\alpha_{7}= & \alpha_{8}=0.5 * \alpha_{1} \\
& \text { and } \\
\alpha_{9}= & \alpha_{10}=\alpha_{11}=0
\end{aligned}
$$

The Wald-test statistic, with 10 degrees of freedom, takes in fact a value of 6.72 ( $p$-value 0.75 ) and 14.42 (p-value 0.15$)$ when imposing the restrictions above to the production function and demand equation coefficients, respectively. At this point the spillover variables are computed defining the weights $w_{i j}$ in accordance with the restrictions defined above. More precisely, the coefficient of $S 53_{\text {same }}$ is normalized to one so that firm $i$ spillover pool is the sum of the R\&D stock of firms of the same size and one or two size-group smaller, the double of the R\&D stock of the firms that are three, four and five group-size smaller, half of the R\&D stock of firms that are one or two size-group bigger. Final weights used in equation (8) are reported in Table 1.2 .

\section{INSERT TABLE 1.2 ABOUT HERE}

Notice that the so-computed pairs of spillover variables, labelled $S 53_{\text {size }}^{\text {proc }}$ and $S 53_{\text {size }}^{\text {good }}$, are greater the larger is the size of the firm. This means that the positive impact of technology diffusion on firm's productivity and demand is

\footnotetext{
${ }^{26}$ We use this particular set of restrictions as it is accepted for both the production funtion and the demand equation. Other simplest restrictions (e.g. $\alpha_{1}=\alpha_{2}=\alpha_{3}=\alpha_{4}=$ $\alpha_{5}=\alpha_{6}=\alpha_{7}$ and $\left.\alpha_{8}=\alpha_{9}=\alpha_{10}=\alpha_{11}=0\right)$ are accepted for the production function but not for the demand equation. We prefer to use a common restriction in order to compare the results obtained.
} 
more likely to affect large firms. ${ }^{27}$ In order to test whether the magnitude of knowledge spillovers changes across industries, a second pairs of variables, $S 18_{\text {size }}^{\text {proc }}$ and $S 18_{\text {size }}^{\text {good }}$ is constructed. For any firm $i$, this is defined as the sum of the R\&D capital of other firms in the same industry as defined by the18-sector classification, weighted by the size of the firms as explained above, minus the R\&D stocks of the firms in the same industry for the 53sector classification. This distinction allows us to test whether the spillovers are larger when the market closeness is greater. Moreover, given that the definition of industry implied by the 18-sector classification is broad enough to embrace vertical relations and complementary products, the $S 18_{\text {size }}^{\text {good }}$ can be used as a proxy to assess the impact of product innovation on downstream firms and/or related business activities.

For any firm, I can determine six out of the eleven variables that are used to estimate the coefficients reported in Table 1.1 above (see footnote 24). Estimation relies then on imposing a value of zero to the missing values. ${ }^{28}$ To test the robustness of our results to this transformation, I follow the same procedure defined above but using 3 size-group instead of $6 .^{29}$ The estimated coefficient for this alternative specification are reported in Table 1.3. The same pattern found using six size-groups shows up again: technology

\footnotetext{
${ }^{27}$ I have constructed alternative measures of spillovers by modifying the definition of the weight, $w_{i j}$. In particular, I have defined spillover pools using the "technological proximity" between firms and their geographical localization. As data on patents per technology field are not available, I have assumed that the technology distance is captured by the gap in the R\&D expenditures. In this case, the weight $w_{i j}$ takes value 1 when the difference in the R\&D efforts is small and it tends to zero as this gap increases. As far as the location is concerned, I wanted to test whether spillovers between firms in the same regions were higher than between firms far away. Estimated coefficients for spillovers using "knowledge gap" and "geographical localization" as weights were either not significantly different from zero or not robust across different specifications. Some variables interacting these alternative approaches have also been constructed but with no remarkable results. These findings confirm that the weightening scheme adopted to compute the spillover variables is fundamental in determing the magnitude and extent of technology dissemination.

${ }^{28}$ See Appendix C for a clarifying example.

${ }^{29}$ Group 1 (small firm): 50 or less employees; group 2 (medium firm): between 51 and 200 employees; group 3 (large firms): more than 200 employees. If a firm belongs to group 2 , we can define the following 3 spillover variables: $S 53_{\text {same }}, S 53_{\text {small } 1}$ and $S 53_{b i g 1}$. For small firms, we can compute the variables $S 53_{\text {same }}, S 53_{b i g 1}$ and $S 53_{b i g 2}$ while for large firms, the associate variables are $S 53_{\text {same }}, S 53_{\text {small } 1}$ and $S 53_{\text {small2 }}$. Here, for each firm, we can compute three out of five spillover variables.
} 
diffusion from small firms to large firms is more relevant than vice versa.. The Wald-test do not reject the validity of the following restrictions: ${ }^{30}$

$$
\begin{aligned}
\alpha_{1}= & \alpha_{2} \\
\alpha_{3}= & 2 * \alpha_{1} \\
\alpha_{4}= & 0.5 * \alpha_{1} \\
& \text { and } \\
\alpha_{5}= & 0
\end{aligned}
$$

This leads to define the weighting scheme reported in Table 1.4.

\section{INSERT TABLE 1.3 and 1.4 ABOUT HERE}

Finally, before explaining the regression results, I would like to mention a number of issues that need to be considered when constructing some of the remaining variables used to estimate the demand and the production function.

First, the dependent variables used to estimate equations $(\mathrm{P})$ and $(\mathrm{G})$ are deflated output, $Y^{p}$, and deflated sales, $Y^{g}$, respectively. Most of the studies in this field use an industry wide price deflator when computing these variables. The underlying hypothesis made is that all firm in the industry sell an homogeneous product, charge the same price and that all the prices move uniformly over time. This hypothesis is obviously not satisfied when firms compete in imperfect competitive environments, as it seems the case for some industries we are studying. In these circumstances the estimation of the parameters can be seriously affected by market power. ${ }^{31}$ The ESEE

\footnotetext{
${ }^{30}$ The Wald-test statistic, with 4 degrees of freedom, takes values 2.11 ( $p$-value 0.72 ) and 4.75 ( $p$-value 0.31) for the production function and the demand equation, respectively.

${ }^{31}$ Klette and Griliches (1995) have examined the biases that can arise when estimation is carried out with deflated revenue, based on a common deflator. They illustrate the problem by modelling a demand equation to add to the production function. Griliches and Mairesse (1995) show that the estimated coefficients will be biased downward on the order of $1 / \mathrm{m}$, where $\mathrm{m}$ is the "mark-up" parameter. The impact of industry wide deflators on the estimation of scale elasticities is studied at length in a companion paper, Ornaghi (2002).
} 
reports the percentage change in the selling price applied by the firms. This allows us to express the output produced in terms of a reference year $t$. By using the log-difference transformation, we then get over the possible biased introduced by the existence of market power. ${ }^{32}$

Second, a proper measure of labour and physical capital has to take into consideration the intensity of utilisation of these variables. By using total hours of work as labour input, $L$, and the rate of capacity utilisation, $U$, we have a more satisfactory specification of the inputs of the production function and consequently better estimates of the parameters can be obtained. As explained in Appendix A, total number of hours is computed using the (mean) normal hours for each worker, plus overtime minus lost hours. This can possibly lead to a measurement error due to rounding-off. I then use number of employees $(E)$ as instruments of the hours of work when estimating the production function.

Last, physical capital used in $\mathrm{R} \& \mathrm{D}$ laboratories and $\mathrm{R} \& \mathrm{D}$ employment have to be excluded from labour and capital measures since these inputs do not produce current output. The database provides information on the number of employees engaged in R\&D activities. This number is subtracted from the total employment reported by the firm when constructing the labour input, $L$, and the relative instrument $E$. In this way I hope to minimise the so called "double-counting" problem. On this point, Hall and Mairesse (1995) affirm that the most important correction is one related to the labour variable.

\section{Regression Results}

According to the econometric framework presented in Section 2, the production function to estimate is the following:

$$
\tilde{y}_{i t}^{p}=\alpha_{1} \tilde{l}_{i t}+\alpha_{2} \tilde{m}_{i t}+\alpha_{3} \tilde{c}_{i t}+\alpha_{4} \tilde{u}_{i t}+\alpha_{5} \tilde{r}_{i t}+\alpha_{6} \tilde{s}_{i t}+\tilde{v}_{i t}
$$

\footnotetext{
${ }^{32}$ Suppose we have data on sales for two consecutive years: $P_{t} * Q_{t}$ and $P_{t+1} * Q_{t+1}$. As we know the percentage price change, we can express the quantities above in terms of the reference year t: $Q_{t} * P_{t}$ and $Q_{t+1} * P_{t}$. At this point if we take the log-difference, we have a measure of the output growth rate $\left(\log \left(Q_{t+1}\right)-\log \left(Q_{t}\right)\right)$, free from price effects.
} 
Recall that small letters with tilde stand for log differences of the variables normalized with respect to the reference firm.

The model is specified in first differences to eliminate the unobservable firm-specific effect, $\mu_{i}$. At the same time, I use instruments to correct for simultaneity. As explained in previous sections, I find that hours of work, $L$, and capacity utilization, $U$, are the variables correlated with the error term, $v$, because of the simultaneous determination with output. The production function is then estimated using instrumental variables with the Generalised Method of Moments (GMM) technique. ${ }^{33}$ The set of instruments used in the first-differenced equations consists of the number of employees, $E$ (adjusted for the "double counting" problem) and the capacity utilization from $t-2$ backwards, and the exogenous variables included in the regressions. ${ }^{34}$ The Sargan test of overidentified restrictions is easily passed in all the specification presented below, confirming the validity of our set of instruments. Moreover, the $m 2$ statistics for serial correlation support the lack of second order serial correlation. ${ }^{35}$ Table 2 below summarizes the estimated coefficients for alternative definitions of the spillover variable.

\section{INSERT TABLE 2 ABOUT HERE}

Given that all the variables are normalized with respect to the reference firm, we expect that the constant is not significantly different from zero. This is actually the case across all specifications, confirming the reliability of the results obtained. The estimated coefficients of materials, labour and physical capital take likely values, similar to other studies on manufacturing firms. The hypothesis of constant returns to scale in standard inputs is always

\footnotetext{
${ }^{33}$ See Arellano and Bond (1991 and 1998).

${ }^{34}$ Simultaneity requires to use lagged levels of hours of work from $t-2$ backwards. As stressed in Section 3.2, I prefer to use number of employees because of measurement errors that can be possibly autocorrelated. In any case, estimation based on lagged level of the endogenous variable give similar results. A test of exogeneity of the capacity utilization based on "Incremental Sargan Test" reveals that this variable has to be considered endogenous, that is why we use past values as instruments. This does not affect point estimates but it affects their precision, as shown in Table 2.

${ }^{35}$ As equations in levels are always assumed to have uncorrelated zero mean error terms, disturbances of specifications in first-differences are expected to present negative first order autocorrelation and absence of higher orders.
} 
rejected at conventional significance level. This confirms a well known finding of most of the empirical studies on the production function: attempts to control for unobservable heterogeneity and simultaneity gives unreasonably low estimates of returns to scale. ${ }^{36}$ The coefficient of capacity utilization shows a positive value but it is not precisely estimated, probably because its lagged levels turn out to be poor instruments. ${ }^{37}$

The main purpose of this analysis is to measure the impact of spillovers on productivity, also in comparison with internal R\&D activities. In column (1), we report the results for the basic specification, where the spillover variable is computed as the unweighted sum of the R\&D capital of all other firms in the same industry. The coefficient of $S 53_{\text {base }}^{\text {proc }}$ is positive but not statistically significant. As we expected, this variable is not enough accurate in reflecting the impact of technology diffusion on firms' productivity. The remaining columns show the estimated coefficient for the spillover variables computed using the weighting matrices based on 6 size-groups - column (2a) and (2b) - and 3 size-groups - column (3a) and (3b). The coefficient of $S 53_{\text {size }}^{\text {proc }}$ is now statistically different from zero across all the specifications. This supports the idea that relative size is a decisive factor in explaining the absorptive capacity of firms. Point estimates of the coefficient of $S 53_{\text {size }}^{\text {proc }}$ show that spillover is less important than internal $R \& D$ investments in determining the productivity of firms. Nevertheless, the relevance of technology diffusion is not questionable, in particular if we consider that the coefficient of the spillover variable is, on average, more than one fifth of the coefficient of internal R\&D capital. ${ }^{38}$ Column $(2 \mathrm{~b})$ and $(3 \mathrm{~b})$ show that the coefficient of $S 18_{\text {size }}^{\text {proc }}$ is not statistically significant. This finding suggests that industrial proximity plays a fundamental role for the technological diffusion of process innovations.

Consider now the demand side as defined in equation $(\mathrm{G})$ above:

\footnotetext{
${ }^{36}$ See Griliches and Mairesse (1995), among others. Blundell and Bond (1998b) are en exception: they accept the constant return restriction when using the system GMM estimator.

${ }^{37}$ Using the same dataset of our study, Garcia et al. (2002) finds a positive and significant value of this variable when treated as an exogenous term. The point estimate they report is close to the one we obtain.

${ }^{38}$ Reported estimates are rather conservative. If we compute the spillover pools with different weighting schemes (consistent with the production function but not with the demand equation estimates of Table 1.1), we obtain higher values for the spillover coefficient, eventually close to 0.05 .
} 


$$
\tilde{y}_{i t}^{g}=\beta_{1} \widetilde{p}_{i t}+\beta_{2} \widetilde{a d}_{i t}+\beta_{3} \widetilde{r}_{i t}+\beta_{4} \widetilde{s}_{i t}+\tilde{v}_{i t}
$$

As explained in Section 2, the major econometric issue related to the demand relationship is the endogeneity of the price. Consequently, this variable has been instrumented using lags from $t-2$ to $t-5$. The Sargan test confirms the validity of the instruments used. Moreover, we fail to reject the null hypothesis of absence of second order autocorrelation across all the specification reported in Table 3. The first three columns of this table presents the results for the basic specification of the spillover variable while the remaining are based on the weighting scheme discussed above.

\section{INSERT TABLE 3 ABOUT HERE}

The constant always shows a small and not significant trend in the growth of real sales. The estimates for the price demand elasticity and advertising show the correct sign and are consistent with previous studies. ${ }^{39}$ As far as the spillover effects are concerned, column (1a) shows a large negative coefficient for the variable $S 53_{\text {size }}^{\text {good }}$. Sales of firm $i$ are negatively affected by any product improvements of competitors (competition effect). Nevertheless, firm $i$ can possibly take advantage of any innovation if it can learn and reproduce its contents (knowledge spillovers). It is not a simple task to disentangle these two opposite effects of competitors' R\&D investments on firm $i$ sales. The large and highly significant negative coefficient of $S 53_{\text {size }}^{\text {good }}$ states that any firm whose variation of knowledge capital is inferior to the representative firm suffers a remarkable contraction in market shares. This variable is then picking up the negative effect of competing against innovative firms. ${ }^{40}$ In order to isolate the (possible) positive effect of knowledge diffusion, it is necessary to augment the specification of the demand equation with variables that control for the drop in sales due to the competition effect. A high relative growth rate of rivals' $R \& D$ capital affects the evolution of the firm market share relative to its competitors once prices are

\footnotetext{
${ }^{39}$ See for instance Garcia et all. (2002).

${ }^{40}$ Recall that the spillover variable is computed as the sum of rivals' R\&D capital; for any two firms, this variable takes a higher value for the firm with lower R\&D stock. See Appendix $\mathrm{C}$ for a simple numeric example.
} 
controlled for. Hence, we can use the change of competitors' market share (mrk share) as a proxy for the competition effect. Moreover, we can use industry concentration (concen) as an overall measure of the impact of R\&D investments on market structure. ${ }^{41}$ Column (1c) in Table 3 shows that under this new specification the coefficient of our spillover variable is now positive, although it is not statistically significant. Interestingly enough, the spillover variable is the only one that records such a remarkable change: all the other variables are rather stable across this alternative formulation. This suggests that these two new regressors are counting for the competition effect, without introducing any (relevant) mispecification of the demand equation. The low precision in estimating the technology diffusion effect call again for a finer definition of the spillover pools a firm can benefit from. Columns (2a) and $(2 \mathrm{~b})$ and columns (3a) and (3b) show that the estimated coefficients for $S 53_{\text {size }}^{\text {good }}$ and $S 18_{\text {size }}^{\text {good }}$ are positive and highly significant. This suggests that learning from rivals plays a fundamental role when it comes to improving the quality of a product. Spanish firms are less R\&D intensive than the average of European firms. Therefore, it is possible that inward FDI works as channels for knowledge spillovers. ${ }^{42}$ The coefficient of $S 18_{\text {size }}$ and $S 53_{\text {size }}$ are of the same order of magnitude, suggesting that technology diffusion goes well beyond a single sector when this is narrowly defined. As suggested in Section 2 spillover effects are potentially wide if we define an industry broadly enough to consider vertical relations and complementary products. The results presented give strong support to this intuitive reasoning. As before, we augment our demand equation with the variables mrk share and concen in order to drain the negative impact of rivals' product innovation on firm $i$ sales due to competition. Results in column (3c) shows that the coefficients of the spillover variables are practically identical to those reported in the other columns. This confirms that the computation of the spillover pools using relative size as a proxy for absorptive capacity is a reliable approach to disclose the existence and the magnitude of technological diffusion.

It is important to notice that the magnitude of spillovers for product and process innovations is rather different, also when compared to the internal R\&D activities. Knowledge diffusion associated with product innovations is

\footnotetext{
${ }^{41}$ I am indebted to Bronwyn Hall for suggesting me this procedure.

${ }^{42}$ Bertschek (1995) shows that imports and FDI play an important role for product and process innovations in the case of German manufacturing firms. We are not aware of any reliable study of this type for Spanish manufacturing industries.
} 
larger in magnitude and extent. This implies that the standard approach based on estimating the production function can only reveal part of the information about spillovers while there are interesting and pervasive aspect of R\&D externalities that cannot be quantify. This finding is related to the point made by Quah (2002) in a study on the New Economy developments. Although his focus is on economic growth and restricted to a particular group of industries, his paper emphasises endogenous growth results from the interaction of demand and supply characteristics, not just productionside developments. In particular the author stresses (pag. 21) that "most profound changes in the New Economy are not productivity or supply-side improvements but instead consumption or demand side changes".

\section{Concluding Remarks}

This paper analyses the impact of knowledge diffusion for product and process R\&D. Our econometric frameworks modifies the standard approach first suggested by Griliches (1979) by adding a demand equation to the standard production function. To the best of my knowledge, there are no similar studies in the empirical literature on spillovers. In constructing the components of the knowledge capital, I introduce two new features. First, as it is not innovation input (R\&D) but innovation output that has a positive impact on the economic performance of a firm, I have modified the (standard) perpetual inventory method by introducing the notion of operative R\&D capital. Second, the spillover variable is computed assuming that the chance of firm $i$ borrowing knowledge from firm $j$ depends on the relative size of the two firms.

Our results suggest that knowledge spillovers play an important role in improving the quality of products and, to a lesser extent, in increasing the productivity of the firm. We find that technological diffusion of product innovations is larger than the one of process innovations both in magnitude and pervasiveness.

These findings have an interesting policy implication. If innovators are unable to appropriate the full benefits of their innovations, then the amount 
of R\&D may be lower than socially optimal, since firms consider only "private" returns on investments when planning their R\&D activities. From our estimations, it emerges that the average gap between private and social rates of return is higher for product innovation than for process innovation. This suggests the opportunity of a different public policy towards taxation of $R \& D$ investments or government subsidies to R\&D activities depending on the type of innovation that firms are focused on. More evidence is obviously required before moving in this direction.

This analysis leaves some important questions unanswered. I have shown that the magnitude of spillovers for product and process innovation is different but further work is needed to determine the channels that actually permit knowledge to flow and how these differ between product and process innovation. Process innovations are often linked to the skills of managers, engineers and technicians and competing firms can hardly benefit from these innovations. One possible channel is through mobility of R\&D engineers. However, firms that are afraid of losing their technological advantages because of this mobility can engage in simple, although costly, activities (e.g., increasing wages and fringe benefits) designed at preventing their own employees from leaving the firm. Product improvements are possibly simpler to learn and replicate, for example through reverse engineering. This line of reasoning can explain the relevant discrepancy between diffusion of product and process innovations presented above. A recent attempt to determine the models or mechanism that actually permit knowledge to flow is the work of Jaffe, Trajtenberg and Fogarty. (2000) based on case-studies of American firms. 


\section{Appendix A: Data and Variable}

\section{A1 Construction of Data Sample}

The survey provides data on manufacturing firms with 10 or more employees. When this was designed, all firms with more than 200 employees were required to participate while a representative sample of about $5 \%$ of the firms with 200 or less employees was randomly selected. In 1990, the first year of the panel, 715 firms with more than 200 employees were surveyed, which accounts for $68 \%$ of all the Spanish firms of this size. Newly established firms have been added every subsequent year to replace the exits due to death and attrition.

We start with a sample of 3,151 firms in an unbalanced panel data. The total number of observations is 18,680 . We then clean our dataset according to the following criteria:

1) We remove all the observations with negative value added. There are 157 such observations, amounting to less than $1 \%$ of the original sample.

2) We drop all observations where the quantity produced by the firm doubled (or the growth rate is less than minus 50\%) but there is not an increase either in the number of employees or in the physical capital of at least $50 \%$ (or a decrease of labour and capital less than minus 25\%). This removes 193 observations (about 1\% of the initial sample).

3) We remove all observations where the internal $R \& D$ capital records a growth rate higher than $400 \%$. This removes other 74 observations.

In total, 424 observations are removed applying the filters above. The subsample we use in our study consists of all the firms that have been surveyed for at least three years. There are 2,430 firms satisfying this condition, for a total number of 16,637 observations. At this point, we remove any observations for which the data required to the estimation are not available. In the tables showing the results of the estimation, we report the exact number of observations making up the final samples.

\section{A2 Description of Variables}

Advertising $(A D)$ : Nominal amount of advertising expenditures deflated by the firms' output price.

Capacity Utilization $(U)$ : Yearly average rate of capacity utilization reported by the firms

Competitors' Market Share (Mrk share): We first determine firm $i$ market share (where the market is defined by the 3-digit CNAE code). Then, we determine the rivals' share as 1 minus firm $i$ market share. 
Concentration (Concen): Herfindal index of industry concentration computed using the market share (as defined above) of all firms in the same 3 -digit industry.

Employment (E): Approximation to the average number of works during the year; it does not consider employees engaged in R\&D activities.

Labour $(L)$ : Labour consists of the total hours of work. It has been constructed using the number of works, adjusted for the double counting of $\mathrm{R} \& \mathrm{D}$ employees, times the normal hours plus overtime and minus lost hours.

Materials (M): Nominal materials are given by the sum of purchases and external services minus the variation of intermediate inventories. We use firms' specific deflator based on the variation in the cost of raw materials and energy as reported by the firm.

Operative R\&D stocks for Process Innovations ( $\left.R^{\text {proc }}\right)$ : This variable is constructed using the perpetual inventory method, assuming a depreciation rate of zero $(\rho=0)$. The word "operative" specifies that only successful innovation is considered in our empirical estimation. Computation is fully explained in Section 3.2.

Operative RED stocks for Product Innovations ( $\left.R^{\text {good }}\right)$ : As for the variable $R^{\text {proc }}$ above, R\&D expenditures are capitalized only when firms achieve a product innovation. See Section 3.2 for further detail.

Output $\left(Y^{p}\right)$ : Nominal output is defined as the sum of sales and the variation of inventories. We deflate the nominal amount using the firms's specific output price as defined below

Physical Capital $(C)$ : It has been constructed capitalising firms' investments in machinery and equipment and using sectorial rates of depreciation. The capital stock does not include buildings. This variable is taken from Martin and Suarez (1997).

Price $(P)$ : Paasche type price index calculated from the variation of price reported in the ESEE. This variable is not expressed in levels but in growth rate. It is used to estimate the price elasticities in the demand equation and to deflate nominal output.

Sales $\left(Y^{g}\right)$ : Amount of total sales reported by the firms deflated by firms' specific output price as defined below.

Size Weighted Spillovers (S53 size): Sum of R\&D capital of other firms in the same industry as defined by the 53-sector classification, weighted by the size of the firms. We use two different weighting matrices as explained in Section 3.2

Size Weighted Spillovers (S18 size): Sum of others' R\&D capital in the 
same industry as defined by the 18-sector classification, weighted by the size of the firms, minus the R\&D stocks of the firms in the same industry at 53 -sector classification. We use two different weighting matrices as explained in Section 3.2

Unweighted Spillovers (S53 $3_{\text {basic }}$ ): Unweighted sum of the R\&D capital of other firms in the same industry at 53-sector classification.

Unweighted Spillovers ( $18_{\text {basic }}$ ): Unweighted sum of others' R\&D capital in the same industry at 18 -sector classification, minus the R\&D stocks of the firms in the same industry at 53-sector classification.

Table A1: R\&D Performers and Innovation

\begin{tabular}{|c|c|c|c|}
\hline Size Group ${ }^{a}$ & $\begin{array}{c}\text { \% of Firms } \\
\text { R\&D performers }\end{array}$ & $\begin{array}{c}\% \text { of Obs } \\
\text { with } \mathrm{dp}=1^{c}\end{array}$ & $\begin{array}{c}\% \text { of Obs } \\
\text { with } \mathrm{dg}=1^{c}\end{array}$ \\
\hline 1 & 27.4 & 20.1 & 16.6 \\
\hline 2 & 40.5 & 28.9 & 21.1 \\
\hline 3 & 60.5 & 34.7 & 27.4 \\
\hline 4 & 77.9 & 36.5 & 31.1 \\
\hline 5 & 91.0 & 48.5 & 36.2 \\
\hline 6 & 93.8 & 59.1 & 45.7 \\
\hline Total & 56.5 & 34.0 & 26.4 \\
\hline
\end{tabular}

Note:

${ }^{a}$ Group 1 : 20 or less employees; group 2: between 21 and 50 employees; group 3: between 51 and 100 employees; group 4: between 101 and 200 employees; group 5: between 201 and 500 employees; group 6: more than 500 employees.

${ }^{b}$ Firms that report non-zero R\&D expenditures in at least one of the year of the surveyed period.

${ }^{c}$ Number of observations in which firms report to have achieve a process innovation $(\mathrm{dp}=1)$ or a product innovation $(\mathrm{dg}=1)$. 
Table A2: Descriptive Statistics

Growth rates of the variable; sample period: 1990-1999.

\begin{tabular}{|c|c|c|c|c|c|}
\hline Variable & Name & Mean & St. Dev. & IQ(5) $)^{a}$ & $\mathrm{IQ}(95)^{a}$ \\
\hline Output & $Y^{p}$ & 0.037 & 0.201 & -0.301 & 0.356 \\
\hline Sales & $Y^{g}$ & 0.037 & 0.309 & -0.348 & 0.408 \\
\hline Labour & $L$ & 0.003 & 0.190 & -0.262 & 0.273 \\
\hline Employment & $E$ & 0.003 & 0.178 & -0.241 & 0.251 \\
\hline Materials & $M$ & 0.026 & 0.322 & -0.450 & 0.494 \\
\hline Physical Capital & $C$ & 0.093 & 0.323 & -0.115 & 0.604 \\
\hline Capacity Utilization $b$ & $U$ & 0.805 & 0.152 & 0.5 & 1 \\
\hline Price & $P$ & 0.014 & 0.059 & -0.051 & 0.086 \\
\hline Advertising & $A D$ & 0.107 & 2.806 & -5.298 & 5.937 \\
\hline Operative $R \& D$ & $R^{\text {proc }}$ & 0.020 & 0.100 & 0.00 & 0.126 \\
\hline Unweigh. Spill. 53 & $S 53_{\text {basic }}^{\text {proc }}$ & 0.015 & 0.404 & -0.387 & 0.461 \\
\hline Size-weigh. Spill. $53^{c}$ & $S 53_{\text {size }}^{\text {proc }}$ & 0.013 & 0.676 & -0.834 & 0.884 \\
\hline Size-weigh. Spill $18^{c}$ & $S 18_{\text {size }}^{\text {proc }}$ & 0.028 & 0.878 & -0.693 & 0.789 \\
\hline Operative $R \& D$ & $R^{g o o}$ & 0.022 & 0.280 & 0.00 & 0.088 \\
\hline Unweigh. Spill. 53 & $S 53_{\text {basic }}^{\text {good }}$ & 0.003 & 0.423 & -0.409 & 0.444 \\
\hline Size-weigh. Spill. $53^{c}$ & $S 53_{\text {size }}^{\text {good }}$ & 0.006 & 0.678 & -0.885 & 0.872 \\
\hline Size-weigh. Spill. $18^{c}$ & $S 18_{\text {size }}^{\text {good }}$ & 0.023 & 0.931 & -0.739 & 0.823 \\
\hline
\end{tabular}

Note:

${ }^{a}$ The IQ is the interquantile range, the value of the variable at the 5 percent and 95 percent level

${ }^{b}$ Variable expressed in Levels

${ }^{c}$ We report descriptive statistics for the size-weighted spillover variable defined using the matrix in Table $1 \mathrm{~B}$ (based on 6 size-group). 


\section{Appendix B: Errors in Variable}

As discussed in Section 3.2, we put a lot of efforts in determining firms' internal R\&D stocks. We consider all possible source of investments (intramural, contracted outside and imported technology), we test for alternative initial values and we take into consideration the (supposed) timing when $\mathrm{R} \& \mathrm{D}$ investments are expected to affect the productivity and the demand faced by the firm (the "operative" capital). Although we are aware that our variable $R$ cannot be considered a perfect measure of the internal $\mathrm{R} \& \mathrm{D}$ capital, we feel confident that it is not affected by (relevant) measurement errors. Point estimates reported in Section 4 are close to other studies and seem to confirm our view. A possible alternative generally employed in the context of panel data is to use past values of the endogenous variable as instruments. Unfortunately, the R\&D capital is highly persistent and lags of this variable in levels turn out to be poor instruments to estimate equations in differences. We also tried to use R\&D employees as an external instruments. However, the Sargan test rejects the validity of this approach.

Note that the bias due to measurement errors is negative when the coefficients for the internal R\&D stock is positive (see Arellano (2000)). Therefore, if we find a positive and significant relationship between productivity and demand changes and internal $\mathrm{R} \& \mathrm{D}$ capital, we might argue that the true relationship is even stronger.

\section{Appendix C: Computing the Spillover Variable.}

This appendix presents two simple numeric example that deals with some difficulties in defining the spillover variables: the first is based on the computation of the spillover variable as the unweighted sum of the R\&D stock of competing firms while in the second, we take into account the size of the firms.

I) Consider the following case:

\begin{tabular}{|c|c|c|c|c|c|c|c|}
\hline Firm & $\begin{array}{c}\text { Indus. } \\
(53)\end{array}$ & $\begin{array}{c}\text { Indus. } \\
(18)\end{array}$ & $\begin{array}{c}R \& D \\
\text { capital }\end{array}$ & $S p 53_{b a}$ & $S p 18_{b a}$ & $\begin{array}{c}S p 53_{b a} \\
\text { (norm.) }\end{array}$ & $\begin{array}{c}S p 18_{b a} \\
\text { (norm.) }\end{array}$ \\
\hline 1 & 1 & 1 & 0 & 45 & 60 & 1.5 & 1 \\
\hline 2 & 1 & 1 & 15 & 30 & 60 & 1 & 1 \\
\hline 3 & 1 & 1 & 30 & 15 & 60 & 0.5 & 1 \\
\hline 4 & 2 & 1 & 10 & 50 & 45 & 1.667 & 1 \\
\hline 5 & 2 & 1 & 10 & 50 & 45 & 1.667 & 1 \\
\hline 6 & 2 & 1 & 40 & 20 & 45 & 0.444 & 1 \\
\hline
\end{tabular}

Note that the six firms belong to two different industries when these 
are defined by the 53-industry classification but they all belong to the same industry when we use the broader 18 sector classification. For any firm $i$, the variable $S P 53_{\text {basic }}$ (column 5) is defined as the sum of the R\&D stock (column 4) of all the other firms in the same industry (for the 53-industry classification). SP18 basic (column 6) is computed as the sum of the R\&D stock of all the other firms in the same industry at 18-sector classification excluding $S P 53_{\text {basic }}$. Recall that we normalize all the variables w.r.t. their 3digit CNAE industry averages, before proceeding to the empirical estimation (to keep things simple, we suppose that the CNAE classification corresponds to the 53-industry classification in column 2). The last two columns report the values of the spillover variables after this normalization. We can draw two main insights from this example: i) a higher value of $S P 53_{\text {basic }}$ necessary indicates a lower internal $\mathrm{R} \& \mathrm{D}$ capital; ii) it is not possible to use $S P 18_{\text {basic }}$ in a regression since it takes value 1 for all the firms.

II) Consider, now, this second example, where we compute the spillover variable taking into account the size of the firm:

\begin{tabular}{|ccccccccc|}
\hline Firm & $\begin{array}{c}\text { Indus. } \\
(53)\end{array}$ & Size & $\begin{array}{c}\text { R\&D } \\
\text { capital }\end{array}$ & $\begin{array}{c}\text { Sp53 } \\
\text { same }\end{array}$ & $\begin{array}{c}\text { Sp53 } \\
\text { small1 }\end{array}$ & $\begin{array}{c}\text { Sp53 } \\
\text { small2 }\end{array}$ & $\begin{array}{c}\text { Sp53 } \\
\text { big1 }\end{array}$ & $\begin{array}{c}\text { Sp53 } \\
\text { big2 }\end{array}$ \\
\hline 1 & 1 & 1 & 0 & 10 & - & - & 40 & 60 \\
2 & 1 & 1 & 10 & 0 & - & - & 40 & 60 \\
3 & 1 & 2 & 10 & 30 & 10 & - & 60 & - \\
4 & 1 & 2 & 30 & 10 & 10 & - & 60 & - \\
5 & 1 & 3 & 20 & 40 & 40 & 10 & - & - \\
6 & 1 & 3 & 40 & 20 & 40 & 10 & - & - \\
\hline
\end{tabular}

We assume that firms belong to three different size classes: small (group 1), medium (group 2) and big (group 3). For any firm, I can compute 3 out of 5 spillover variables reported above. For example, for firm 1, I can compute the spillover from firms of the same size, $S P 53_{\text {same }}$ (which corresponds to the R\&D capital of firm 2), from firms one size-group bigger, $S P 53_{b i g 1}$ (which is the sum of the R\&D capital of firm 3 and 4) and from firms two size-group bigger, $S P 53_{\text {same }}$ (which corresponds to the sum of the R\&D capital of firm 5 and 6 ). To estimate the coefficients of these 5 variables, we replace missing observations with zero before normalizing w.r.t. their average values. This transformation has the effect of rescaling the relative value of all the spillover variables (except $S P 53_{\text {same }}$ ) since it reduces their means. Our approach relies implicitly on the assumption that the impact on any firm belonging to size class $k$ (with $k=1,2,3$ ) of the spillovers coming from competitors in size 
class $k+s$ (with $|s| \leq 2$ ) depends on $s$ but not on $k$ (e.g. $S P 53_{\text {small1 }}$ measures technology diffusion from median firm to big firm and from small firm to medium firm, at the same time). Although this modus operandi can be open to criticism, we need to observe that: i) the sources and channels of technology diffusion are so complex that any approach used to get a proxy for the spillover pools can be criticized and defended at the same time. We feel that the differences in size (more than the absolute size of the firm) can play an important role in defining differences in the absorptive capacity; ii) we check for the robustness of our results (in particular to the replacement of missing observations with zeros) by defining two different size classification (one with 6 groups and the other with 3 groups) and we obtain similar and sensible results, as discussed in Section 3.2; moreover, estimations have been run also using the balanced panel sample with no sensible differences in the results obtained (so that these are robust also to changes in the sample composition); iii) the estimated coefficients of these variables are not used to make inferences about spillover in product and process innovation (the ultimate objective of our analysis) but are simply used as weights to compute a finer spillover variable than the basic one. We could impose similar weights ex-ante (on the base of some assumptions) without going through this procedure. For example, we compute the spillover variable summing only the $\mathrm{R} \& \mathrm{D}$ stocks of all the firms of the same size or smaller (this is equivalent to a weighting matrix with value 1 if $\operatorname{size}($ firm $i) \geq \operatorname{size}($ firm $j$ ) and zero otherwise). We find that the general results presented in Section 4 are still valid under this (ad hoc) approach. 


\section{Appendix D: Definition of Industrial Sectors}

The ESEE reports the 3-digit CNAE sector that firms belong to. There are 122 different manufacturing sectors. To construct the spillover variables, we defined two different industrial classification: one grouping those 3-digit sectors into 53 industries and another one into 18 industries. In other words, the sectors defined by the CNAE has been grouped into 53 industries and the later has been successively grouped into 18 (larger) industries.

\section{Table D1: 18 Industry Classification}

\begin{tabular}{|l|l|l|}
\hline Sector & Definition & 3-digit CNAE \\
\hline 1 & Ferrous and non ferrous metals & 221 to 224 \\
2 & Non-metallic minerals & 240 to 249 \\
3 & Chemical products & 251 to 255 \\
4 & Metal products & 311 to 319 \\
5 & Industrial and agricultur machinery & 321 to 329 \\
6 & Office and data processing machine & 330,391 to 399 \\
7 & Electrical and electronic goods & 341 to 347,351 \\
& & to 355 \\
9 & Vehicles, cars and motors & 361 to 363 \\
& Other transport equipment & 371 to 372,381 \\
10 & Meat and preserved meat & to 389 \\
11 & Food and tobacco & 413 \\
& & 411 to 412,414 \\
12 & Beverages & to 423,429 \\
13 & Textiles and clothing & 424 to 428 \\
& & 431 to 439,453 \\
14 & Leather and shoes & to 456 \\
& & 441 to 442,451 \\
15 & Timber and furniture & to 452 \\
17 & Paper and printing products & 461 to 468 \\
18 & Rubber and Plastic products & 471 to 475 \\
& Other manufacturing products & 481 to 482 \\
& & 491 to 495 \\
\hline
\end{tabular}


Table D2: 53 Industry Classification

\begin{tabular}{|c|c|c|}
\hline Sector & Definition & 3-digit CNAE \\
\hline 1 & Ferrous and non ferrous metals & 221 to 224 \\
\hline 2 & Structural clay products & 240 to 241 \\
\hline 3 & Concrete & 242,248 to 249 \\
\hline 4 & Concrete mixer and other by-products & 243 \\
\hline 5 & Stone and ceramic & 244 to 245,247 \\
\hline 6 & Glass & 246 \\
\hline 7 & $\begin{array}{l}\text { Inorganic and organic chemicals and syn- } \\
\text { tetic materials }\end{array}$ & 251 to 252 \\
\hline 8 & $\begin{array}{l}\text { Paints, Varnishes and other chemical } \\
\text { products }\end{array}$ & 253 \\
\hline 9 & Drugs & 254 \\
\hline 10 & Soap and Detergents & 255 \\
\hline 11 & $\begin{array}{l}\text { Metal foundaries and primary smelting } \\
\text { and refining }\end{array}$ & 311 to 313 \\
\hline 12 & $\begin{array}{l}\text { Fabricated structural metal products } \\
\text { (doors, frames, ..) }\end{array}$ & 314 \\
\hline 13 & Heating equipment & 315,319 \\
\hline 14 & $\begin{array}{l}\text { Miscellaneous metal products (bolts, nuts, } \\
\text { screws, ..) }\end{array}$ & 316 \\
\hline 15 & Farm machinery and equipment & 321 \\
\hline 16 & $\begin{array}{l}\text { Metal work machinery and textile } \\
\text { machinery }\end{array}$ & 322 to 323 \\
\hline 17 & Machinery for chemical industry & 324 \\
\hline 18 & $\begin{array}{l}\text { Mining and construction machinery and } \\
\text { convey equipments }\end{array}$ & 325 to 326 \\
\hline 19 & $\begin{array}{l}\text { Engines and turbines and other machiner- } \\
\text { ies, not elsewhere classified }\end{array}$ & 327 to 329 \\
\hline 20 & $\begin{array}{l}\text { Office equipments and medical and photo- } \\
\text { graphic instruments }\end{array}$ & 330,391 to 399 \\
\hline 21 & $\begin{array}{l}\text { Electric transmission and wiring } \\
\text { equipment }\end{array}$ & 341 to 342 \\
\hline 22 & Electrical industrial apparatus & 343 to 344 \\
\hline 23 & Houshold appliances & 345 \\
\hline 24 & Electric lightening & 346 \\
\hline
\end{tabular}




\begin{tabular}{|c|c|c|}
\hline Sector & Definition & 3-digit CNAE \\
\hline 25 & Miscellaneous electric products & 347 \\
\hline 26 & $\begin{array}{l}\text { Telephone apparatus and radio } \\
\text { broadcasting }\end{array}$ & 351 to 353 \\
\hline 27 & Electronic componets & 354 to 355 \\
\hline 28 & Motor vehicles and motorcycles & 361 to 362 \\
\hline 29 & Motor vehicles parts and accessories & 363 \\
\hline 30 & Ship and boat building and repairing & 371 to 372 \\
\hline 31 & Railroad and aircraft equipement & 381 to 383,389 \\
\hline 32 & Oil and Milk production and derivatives & $\begin{array}{l}411 \text { to } 412,414 \\
\text { to } 415\end{array}$ \\
\hline 33 & Livestock & 413 \\
\hline 34 & Fishing & 416 to 418 \\
\hline 35 & Bakery products & 419 \\
\hline 36 & Sugar and cacao & 420 to 421 \\
\hline 37 & Wine, beer and alchoolic beverages & 424 to 428 \\
\hline 38 & Other diary products and tobacco & 422 to 423,429 \\
\hline 39 & $\begin{array}{l}\text { Cotton and silk products (including dye- } \\
\text { ing and finishing) }\end{array}$ & $\begin{array}{l}431,433 \text { to } 434 \\
436,439\end{array}$ \\
\hline 40 & $\begin{array}{l}\text { Wool products (including dyeing and } \\
\text { finishing) }\end{array}$ & $432,435,437$ \\
\hline 41 & Leather products: luggage and gloves & 441 to 442 \\
\hline 42 & Footwear & 451 to 452 \\
\hline 43 & $\begin{array}{l}\text { Apparel and other finished products made } \\
\text { from fabrics }\end{array}$ & 453 \\
\hline 44 & Leather products: fur goods & 454 to 456 \\
\hline 45 & $\begin{array}{l}\text { Timber and wood products (exept } \\
\text { forniture) }\end{array}$ & 461 to 467 \\
\hline 46 & Forniture & 468 \\
\hline 47 & Pulp, paper and paperboard mills & 471 to 472 \\
\hline 48 & $\begin{array}{l}\text { Converted paper and paperboard } \\
\text { products }\end{array}$ & 473 \\
\hline 49 & Commercial printing & 474 \\
\hline 50 & $\begin{array}{l}\text { Newspapers, periodicals and books } \\
\text { publishing }\end{array}$ & 475 \\
\hline 51 & Rubber products & 481 \\
\hline 52 & Plastic products & 482 \\
\hline 53 & Other manufacturing products & 491 to 495 \\
\hline
\end{tabular}




\section{References}

[1] Arellano, M. (2000), "Panel Data Econometrics", Chap. 4, still unpubblised.

[2] Arellano, M. and Bond S. (1998), "Dynamic Panel Data Estimation using DPD98 for Gauss: A Guide for Users", Oxford University.

[3] Arellano, M. and Bond S. (1991), "Some Test of Specification for Panel Data: Monte Carlo Evidence and an Application to Employment Equations". Review of Economic Studies, Vol. 58, pp. 277-297.

[4] Benito, P. (2000), "R\&D Productivity and Spillovers: Evidence from Spanish Panel Data", Ph D. Thesis, Chap. 1, Universidad de Valencia.

[5] Bertschek, I. (1995), "Product and Process Innovation as a Response to Increasing Imports and Foreign Direct Investment". The Journal of Industrial Economics, Vol.43, pp. 341-357.

[6] Blundell, R.W. and Bond S.R. (1998a), "Initial Conditions and Moment Restrictions in Dynamic Panel Data Models". Journal of Econometrics, Vol. 87, pp. 115-143.

[7] Blundell, R.W. and Bond S.R. (2000), "GMM estimation with Persistent Panel Data: An Application to Production Functions". Econometric Reviews, Vol. 19, pp. 321-340.

[8] Cassiman, B. and Veugelers R.(1999) "R\&D Cooperation and Spillovers: Some Empirical Evidence", CEPR Discussion Paper, No. 2330.

[9] Garcia, A., Jaumandreu, J. and Rodriguez C. (2002), "Innovation and Jobs: Evidence from Manufacturing Firms". mimeo, Universidad Carlos III de Madrid.

[10] Greene, W. H. (1997), "Econometric Analysis". Prentice-Hall International, London.

[11] Griliches, Z (1992), "The Search for R\&D Spillovers". Scandinavian Journal of Economics, Vol. 94, pp. S29-47.

[12] Griliches, Z. (1979), "Issues in Assessing the Contribution of R\&D to Productivity Growth". Bell Journal of Economics, Vol. 10, pp. 92-116. 
[13] Griliches, Z. and Mairesse J. (1995), "Production Function: The Search for Indentification". NBER Working Paper, No. 5067.

[14] Griliches, Z. and Mairesse J. (1984), "Productivity and R\&D at the Firm Level". In RESD, Patents and Productivity, ed. Zvi Griliches. University of Chicago Press.

[15] Hall, B.H and Mairesse J. (1995), "Exploring the Relationship between R\&D and Productivity in French Manufacturing Firms". Journal of Econometrics, Vol. 65, pp. 263-293.

[16] Hall, B.H. Griliches Z. and Hausman J.A. (1986), "Is there a second (technological opportunity) factor?". International Economic Review, Vol. 27, pp. 265-283.

[17] Hernan, R., Marin, P. and Siotis G. (2003) "An Empirical Evaluation of the Determinants of Research Joint Venture Formation", Journal of Industrial Economics, forthcoming.

[18] Hulten, C.R. (2000), "Total Factor Productivity: A short Biography". NBER Working Paper, No. 7471.

[19] Instituto Nacional de Estadistica (1999), Estadistica sobre actividades en investigación cientificas y desarollo tecnológico, Spain.

[20] Jaffe, A.B. (1986), "Technological Opportunity and Spillovers of R\&D: Evidence from Firms' Patents, Profits, and Market Value". American Economic Review, Vol. 76, pp. 984-1001.

[21] Jaffe. A.B. Trajtenberg M. and Fogarty M.S. (2000), "Knowledge Spillovers and Patent Citations: Evidence from a Survey of Inventors", American Economic Review, Vol. 90, pp. 215-218.

[22] Klette, T.J. (1999), "Market Power, Scale Economies and Productivity: Estimates from a Panel of Establishment Data". The Journal of Industrial Economics, Vol. 48, pp. 451-476.

[23] Klette, T.J. (1996), "R\&D, Scope Economies, and Plant Performance". RAND Journal of Economics, Vol. 27, pp. 502-522. 
[24] Klette, T.J. and Griliches Z (1996), "The inconsistency of Common Scale Estimators when Output Prices are Unobserved and Endogenous". Journal of Applied Econometrics, Vol. 11, pp. 343-361.

[25] Levin, R.C. and Reiss P.C. (1988), "Cost-reducing and Demand-creating R\&D with Spillovers". RAND Journal of Economics, Vol. 19, pp538-556.

[26] Los, B. and Verspagen B. (2000), "R\&D Spillovers and Productivity: Evidence from U.S. Manufacturing Microdata". Empirical Economics, Vol. 25, pp. 127-148.

[27] Mansfield, E. (1983), "Technological Change and Market Structure: An Empirical Study". American Economic Review, Vol. 73, pp. 205-209.

[28] Mansfield, E., Rapoport J., Romeo A., Wagner S., and Beardsley G. (1977), "Social and Private Rates of Return from Industrial Innovations". Quarterly Journal of Economics, Vol. 41, pp. 221-240.

[29] Marin, P., Siotis G. and Hernan R. (2000) "An Empirical Evaluation of the Determinants of Research Joint Venture Formation", CEPR Discussion Paper, No. 2442.

[30] Martin, A. and Suarez C. (1997), "El Stock de Capital para las Empresas de la Encuesta sobre Estrategias Empresariales". Documento Interno n.13, Programa de Investigaciones Económicas, Fundación Empresa Pública.

[31] Nadiri, M.I. (1993), "Innovation and Technological Spillovers". NBER Working Paper, No. 4423.

[32] Ornaghi, C. (2002), "Assessing the Effects of Measurement Errors on the Estimation of the Production Function". mimeo, Universidad Carlos III de Madrid.

[33] Pakes, A. and Schankerman M. (1984), "The Rate of Obsolescence of Patents, Research Gestation Lags, and the Private Rate of Return to Research Resources". In REDD, Patents and Productivity, ed. Zvi Griliches. University of Chicago Press.

[34] Quah, D. (2002), "Technology Dissemination and Economic Growth: Some Lessons for the New Economy". CEPR Discussion Paper, No. 3207 . 


\section{TABLES}

Table 1.1: Spillovers for 6 Size-Group

\begin{tabular}{|l|c|cc|cc|}
\hline \multicolumn{1}{|c|}{ Variable } & Coeff & \multicolumn{2}{|c|}{$\begin{array}{c}\text { Production } \\
\text { (1) }\end{array}$} & \multicolumn{2}{c|}{$\begin{array}{c}\text { Demand }^{\mathbf{a}} \\
\text { (2) }\end{array}$} \\
\hline Other variables & & & \multicolumn{2}{|c|}{ Incl. } & \multicolumn{2}{|c|}{ Incl. } \\
S53 & & & & \\
same & $\alpha_{1}$ & $0.0032^{* *}$ & $(0.0013)$ & $0.0122^{* * *}$ & $(0.0016)$ \\
$S 53_{\text {small } 1}$ & $\alpha_{2}$ & $0.0022^{* *}$ & $(0.0011)$ & $0.0150^{* * *}$ & $(0.0015)$ \\
$S 53_{\text {small } 2}$ & $\alpha_{3}$ & $0.0021^{*}$ & $(0.0012)$ & $0.0140^{* * *}$ & $(0.0015)$ \\
$S 53_{\text {small } 3}$ & $\alpha_{4}$ & $0.0066^{* * *}$ & $(0.0015)$ & $0.0225^{* * *}$ & $(0.0018)$ \\
$S 53_{\text {small }}$ & $\alpha_{5}$ & $0.0050^{* * *}$ & $(0.0015)$ & $0.0219^{* * *}$ & $(0.0018)$ \\
$S 53_{\text {small5 }}$ & $\alpha_{6}$ & $0.0059^{* * *}$ & $(0.0019)$ & $0.0226^{* * *}$ & $(0.0019)$ \\
$S 53_{\text {big1 }}$ & $\alpha_{7}$ & $0.0030^{* * *}$ & $(0.0010)$ & $0.0060^{* * *}$ & $(0.0012)$ \\
$S 53_{\text {big2 }}$ & $\alpha_{8}$ & 0.0006 & $(0.0009)$ & $0.0037^{* * *}$ & $(0.0010)$ \\
$S 53_{\text {big3 }}$ & $\alpha_{9}$ & 0.0005 & $(0.0010)$ & $-0.0021^{*}$ & $(0.0013)$ \\
$S 53_{\text {big4 }}$ & $\alpha_{10}$ & -0.0004 & $(0.0011)$ & -0.0022 & $(0.0014)$ \\
$S 53_{\text {big5 }}$ & $\alpha_{11}$ & 0.0001 & $(0.0010)$ & -0.0005 & $(0.0011)$ \\
\hline
\end{tabular}

Heteroskedasticity robust standard errors shown in parentheses. * significant at $10 \%$ level; ** significant at $5 \% ; * *$ significant at $1 \%$.

${ }^{a}$ Estimation is by generalized instrumental variables regression after first differencing.

${ }^{\mathrm{b}}$ For the production function, this includes labour, material, physical capital, capacity utilization and internal R\&D capital (for process innovation). For the demand side, it includes prices, advertising and internal R\&D capital (for product innovation).

Table 1.2: Weighting Matrix

\begin{tabular}{|c|c|c|c|c|c|c|}
\hline Firm $i$ & \multicolumn{7}{|c|}{ Firm $j$ size-group } \\
size-group $^{\text {a }}$ & $\mathbf{1}$ & $\mathbf{2}$ & $\mathbf{3}$ & $\mathbf{4}$ & $\mathbf{5}$ & $\mathbf{6}$ \\
\hline $\mathbf{1}$ & 1 & 0.5 & 0.25 & 0 & 0 & 0 \\
$\mathbf{2}$ & 1 & 1 & 0.5 & 0.25 & 0 & 0 \\
$\mathbf{3}$ & 1 & 1 & 1 & 0.5 & 0.25 & 0 \\
$\mathbf{4}$ & 2 & 1 & 1 & 1 & 0.5 & 0.25 \\
$\mathbf{5}$ & 2 & 2 & 1 & 1 & 1 & 0.5 \\
$\mathbf{6}$ & 2 & 2 & 2 & 1 & 1 & 1 \\
\hline
\end{tabular}

This weighting scheme is derived from the restriction on the coefficient reported in Table 1.1. The six size-groups are: group $1=20$ or less employees; group $2=$ between 21 and 50 eimpoyees; group $3=$ between 51 and 100 employees; group $4=$ between 101 and 200 employees; group $5=$ between 201 and 500 employees; group $6=$ more than 500 employees. Look at the first row; when firm $i$ has less than 20 employees (group 1) can benefit from the entire R\&D capital of other firms in the same size-group (group 1), from half of the R\&D capital of other firms in size-group 2 and from a quarter of the R\&D capital of firms in sizegroup 3; this firm cannot take advantage of the research efforts undertaken by large firms (group 4, 5 and 6). 
Table 1.3: Spillovers for 3 Size-Group

\begin{tabular}{|l|c|ll|ll|}
\hline \multicolumn{1}{|c|}{ Variable } & Coeff & \multicolumn{2}{|c|}{$\begin{array}{c}\text { Production } \\
\text { (1) }\end{array}$} & \multicolumn{2}{c|}{$\begin{array}{c}\text { Demand }^{\mathbf{a}} \\
\text { (2) }\end{array}$} \\
\hline Other variables & & & \multicolumn{2}{|c|}{ Incl. } & \multicolumn{2}{c|}{ Incl. } \\
S53 & & & & \\
same & $\alpha_{1}$ & $0.0051^{* *}$ & $(0.0022)$ & $0.0219^{* * *}$ & $(0.0040)$ \\
$S 53_{\text {small }}$ & $\alpha_{2}$ & $0.0033^{* *}$ & $(0.0016)$ & $0.0170^{* * *}$ & $(0.0026)$ \\
$S 53_{\text {small } 2}$ & $\alpha_{3}$ & $0.0053^{* * *}$ & $(0.0019)$ & $0.0312^{* * *}$ & $(0.0035)$ \\
$S 53_{\text {big1 }}$ & $\alpha_{4}$ & $0.0025^{* *}$ & $(0.0012)$ & $0.0104 * * *$ & $(0.0019)$ \\
$S 53_{\text {big2 }}$ & $\alpha_{5}$ & 0.0008 & $(0.0014)$ & -0.0012 & $(0.0024)$ \\
\hline
\end{tabular}

Heteroskedasticity robust standard errors shown in parentheses. * significant at $10 \%$ level; ** significant at $5 \%$; *** significant at $1 \%$.

${ }^{\text {a}}$ Estimation is by generalized instrumental variables regression after first differencing.

${ }^{\mathrm{b}}$ For the production function, this includes labour, material, physical capital, capacity utilization and internal R\&D capital (for process innovation). For the demand side, it includes prices, advertising and internal R\&D capital (for product innovation).

Table 1.4: Weighting Matrix

\begin{tabular}{|c|c|c|c|}
\hline Firm $i$ & \multicolumn{3}{|c|}{ Firm $j$ size-group } \\
size-group $^{\text {a }}$ & $\mathbf{1}$ & $\mathbf{2}$ & $\mathbf{3}$ \\
\hline $\mathbf{1}$ & 1 & 0.5 & 0 \\
$\mathbf{2}$ & 1 & 1 & 0.5 \\
$\mathbf{3}$ & 2 & 1 & 1 \\
\hline
\end{tabular}

This weighting scheme is derived from the restriction on the coefficient reported in Table 1.3. The three size-groups are: group $1=50$ or less employees; group $2=$ between 51 and 200 eimpoyees; group $3=$ more than 200 employees. Look at the first row; when firm $i$ has less than 50 employees (group 1) can benefit from the entire R\&D capital of other firms in the same size-group (group 1), from half of the R\&D capital of other firms in size-group 2 but it cannot take advantage of the research efforts undertaken by large firms (group 3). 
Table 2: Production Function

Sample Period: 1991-1999;

Dependent Variable: Output growth rate

Estimation Method: GMM estimates ${ }^{\mathrm{a}}$

\begin{tabular}{|c|c|c|c|c|c|}
\hline Variables & $\begin{array}{c}\text { Basic } \\
\text { (1) }\end{array}$ & $\begin{array}{c}6 \text { Size-Gr } \\
\text { (2a) }\end{array}$ & $\begin{array}{l}6 \text { Size-Gr } \\
\text { (2b) }\end{array}$ & \begin{tabular}{|c|} 
3 Size-Gr \\
(3a)
\end{tabular} & $\begin{array}{c}3 \text { Size-Gr } \\
(\mathbf{3 b})\end{array}$ \\
\hline constant & $\begin{array}{l}-0.003 \\
(0.003)\end{array}$ & $\begin{array}{l}-0.003 \\
(0.003)\end{array}$ & $\begin{array}{l}-0.003 \\
(0.003)\end{array}$ & \begin{tabular}{|l|}
-0.003 \\
$(0.002)$
\end{tabular} & $\begin{array}{l}-0.003 \\
(0.002)\end{array}$ \\
\hline$l$ & $\begin{array}{l}0.354 * * * \\
(0.072)\end{array}$ & $\begin{array}{l}0.326^{* * * *} \\
(0.081)\end{array}$ & $\begin{array}{l}0.311^{* * *} \\
(0.083)\end{array}$ & $\begin{array}{l}0.313^{* * *} \\
(0.079)\end{array}$ & $\begin{array}{l}0.312^{* * * *} \\
(0.079)\end{array}$ \\
\hline$m$ & $\begin{array}{l}0.380 * * * \\
(0.020)\end{array}$ & $\begin{array}{l}0.391 * * * \\
(0.021)\end{array}$ & $\begin{array}{l}0.394 * * * \\
(0.021)\end{array}$ & $\begin{array}{l}0.394 * * * \\
(0.021)\end{array}$ & $\begin{array}{l}0.394 * * * \\
(0.021)\end{array}$ \\
\hline$c$ & $\begin{array}{l}0.089^{* * * *} \\
(0.015)\end{array}$ & $\begin{array}{l}0.084 * * * \\
(0.015)\end{array}$ & $\begin{array}{l}0.085^{* * *} \\
(0.015)\end{array}$ & $\begin{array}{l}0.085^{* * * *} \\
(0.015)\end{array}$ & $\begin{array}{l}0.085^{* * *} \\
(0.015)\end{array}$ \\
\hline$u$ & $\begin{array}{l}0.051 \\
(0.068)\end{array}$ & $\begin{array}{l}0.032 \\
(0.069)\end{array}$ & $\begin{array}{l}0.031 \\
(0.069)\end{array}$ & $\begin{array}{l}0.038 \\
(0.069)\end{array}$ & $\begin{array}{l}0.039 \\
(0.069)\end{array}$ \\
\hline$r^{\text {proc }}$ & $\begin{array}{l}0.110^{* * * *} \\
(0.026)\end{array}$ & $\begin{array}{l}0.097 * * * \\
(0.023)\end{array}$ & $\begin{array}{l}0.098^{* * * *} \\
(0.024)\end{array}$ & $\begin{array}{l}0.098^{* * * *} \\
(0.023)\end{array}$ & $\begin{array}{l}0.098 * * * \\
(0.023)\end{array}$ \\
\hline$s 53^{\text {proc }}$ & $\begin{array}{l}0.034 \\
(0.042)\end{array}$ & $\begin{array}{l}0.016^{*} \\
(0.009)\end{array}$ & $\begin{array}{l}0.018^{* *} \\
(0.008)\end{array}$ & $\begin{array}{l}0.021 * * * \\
(0.007)\end{array}$ & $\begin{array}{l}0.023 * * \\
(0.008)\end{array}$ \\
\hline$s 18^{\text {proc }}$ & 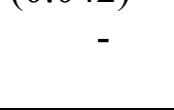 & , & $\begin{array}{l}-0.002 \\
(0.007)\end{array}$ & & $\begin{array}{l}-0.005 \\
(0.007)\end{array}$ \\
\hline $\begin{array}{l}\text { Obs } \\
\text { Sarga }\end{array}$ & $\begin{array}{l}11,004 \\
76.9(70)\end{array}$ & \begin{tabular}{|l|}
11,004 \\
$80.5(70)$
\end{tabular} & $\begin{array}{l}11,004 \\
80.6(70)\end{array}$ & \begin{tabular}{|l|}
11,004 \\
$80.0(70)$
\end{tabular} & $\begin{array}{l}11,004 \\
80.2(70)\end{array}$ \\
\hline & -11.6 & -12. & -12.33 & -12.32 & -12.32 \\
\hline $\mathbf{m 2}^{\mathrm{c}}$ & -1.47 & -1.58 & -1.58 & $\mid-1.71$ & $\mid-1.71$ \\
\hline
\end{tabular}

Heteroskedasticity robust standard errors shown in parentheses. * significant at $10 \%$ level; ** significant at $5 \% ; * *$ significant at $1 \%$.

${ }^{a}$ Estimation is by generalized instrumental variables regression after first differencing. IVs: number of workers $(E)$ and capacity utilization $(U)$ lagged levels from $t-2$ and all earlier periods.

${ }^{\mathrm{b}}$ Sargan test of overidentifying restrictions with degrees of freedom reported in parentheses

${ }^{c} \mathrm{~m} 1$ and $\mathrm{m} 2$ Arellano and Bond (1991) test for first order and second order autocorrelation. 
Table 3: Demand Equation

Sample Period: 1991-1999;

Dependent Variable: Output growth rate

Estimation Method: GMM estimates ${ }^{\mathrm{a}}$

\begin{tabular}{|c|c|c|c|c|c|c|c|c|}
\hline Variables & $\begin{array}{c}\text { Basic } \\
\text { (1a) }\end{array}$ & $\begin{array}{c}\text { Basic } \\
\text { (1b) }\end{array}$ & $\begin{array}{l}\text { Basic } \\
\text { (1c) }\end{array}$ & $\begin{array}{c}6 \text { Size-Gr } \\
(2 a)\end{array}$ & $\begin{array}{c}6 \text { Size-Gr } \\
(2 b)\end{array}$ & $\begin{array}{c}6 \text { Size -Gr } \\
(2 c)\end{array}$ & $\begin{array}{c}3 \text { Size -Gr } \\
\text { (3a) }\end{array}$ & $\begin{array}{c}3 \text { Size-Gr } \\
(3 b)\end{array}$ \\
\hline constant & $\begin{array}{l}-0.003 \\
(0.003)\end{array}$ & $\begin{array}{l}-0.008 * * \\
(0.003)\end{array}$ & $\begin{array}{l}0.002 \\
(0.003)\end{array}$ & $\begin{array}{l}-0.001 \\
(0.003)\end{array}$ & $\begin{array}{l}-0.002 \\
(0.003)\end{array}$ & $\begin{array}{l}0.001 \\
(0.003)\end{array}$ & $\begin{array}{l}-0.001 \\
(0.003)\end{array}$ & $\begin{array}{l}-0.002 \\
(0.003)\end{array}$ \\
\hline$p$ & $\begin{array}{l}-2.205 * * * \\
(0.643)\end{array}$ & $\begin{array}{l}-2.157 * * * \\
(0.643)\end{array}$ & $\begin{array}{l}-1.762 * * * \\
(0.551)\end{array}$ & $\begin{array}{l}-2.177 * * * \\
(0.627)\end{array}$ & $\begin{array}{l}-2.205 * * * \\
(0.631)\end{array}$ & $\begin{array}{l}-1.761 * * * \\
(0.539)\end{array}$ & $\begin{array}{l}-2.174 * * * \\
(0.634)\end{array}$ & $\begin{array}{l}-2.183 * * * \\
(0.633)\end{array}$ \\
\hline$a d$ & $\begin{array}{l}0.013 * * * \\
(0.002)\end{array}$ & $\begin{array}{l}0.012 * * * \\
(0.002)\end{array}$ & $\begin{array}{l}0.011 * * * \\
(0.002)\end{array}$ & $\begin{array}{l}0.013 * * * \\
(0.002)\end{array}$ & $\begin{array}{l}0.012 * * * \\
(0.002)\end{array}$ & $\begin{array}{l}0.010 * * * \\
(0.002)\end{array}$ & $\begin{array}{l}0.013 * * * \\
(0.002)\end{array}$ & $\begin{array}{l}0.013 * * * \\
(0.002)\end{array}$ \\
\hline$r^{\text {proc }}$ & $\begin{array}{l}0.263 * * * \\
(0.026)\end{array}$ & $\begin{array}{l}0.219 * * * \\
(0.026)\end{array}$ & $\begin{array}{l}0.206 * * * \\
(0.023)\end{array}$ & $\begin{array}{l}0.243 * * * \\
(0.026)\end{array}$ & $\begin{array}{l}0.235 * * * \\
(0.024)\end{array}$ & $\begin{array}{l}0.175^{* * * *} \\
(0.020)\end{array}$ & $\begin{array}{l}0.253 * * * \\
(0.025)\end{array}$ & $\begin{array}{l}0.246 * * * \\
(0.024)\end{array}$ \\
\hline$s 53^{\text {proc }}$ & $\begin{array}{l}-0.419 * * * \\
(0.128)\end{array}$ & $\begin{array}{l}-0.067 \\
(0.172)\end{array}$ & $\begin{array}{l}0.134 \\
(0.106)\end{array}$ & $\begin{array}{l}0.117 * * * \\
(0.013)\end{array}$ & $\begin{array}{l}0.085 * * * \\
(0.012)\end{array}$ & $\begin{array}{l}0.069 * * * \\
(0.011)\end{array}$ & $\begin{array}{l}0.085^{* * * *} \\
(0.011)\end{array}$ & $\begin{array}{l}0.060 * * * \\
(0.011)\end{array}$ \\
\hline$s 18^{\text {proc }}$ & - & - & - & - & $\begin{array}{l}0.090 * * * \\
(0.013)\end{array}$ & $\begin{array}{l}0.094 * * * \\
(0.012)\end{array}$ & - & $\begin{array}{l}0.087 * * * \\
(0.014)\end{array}$ \\
\hline mrk share & - & $\begin{array}{l}-2.496 * * * \\
(0.261)\end{array}$ & $\begin{array}{l}-3.240 * * * \\
(0.166)\end{array}$ & - & - & $\begin{array}{l}-3.126 * * * \\
(0.156)\end{array}$ & - & - \\
\hline concen & - & - & $\begin{array}{l}-2.346 * * * \\
(0.122)\end{array}$ & - & - & $\begin{array}{l}-2.353 * * * \\
(0.121)\end{array}$ & - & - \\
\hline Obs & 13,539 & 13,539 & 13,539 & 13,539 & 13,539 & 13,539 & 13,539 & 13,539 \\
\hline Sargan T (df $)^{b}$ & $18.6(25)$ & $20.0(25)$ & $22.1(25)$ & $19.9(25)$ & $19.5(25)$ & $21.6(25)$ & $19.6(25)$ & $18.6(25)$ \\
\hline $\mathbf{m} \mathbf{1}^{\mathrm{c}}$ & -5.96 & -5.71 & -5.39 & -6.27 & -6.33 & -5.62 & -6.08 & -6.12 \\
\hline $\mathbf{m} \mathbf{2}^{\mathrm{c}}$ & -1.74 & -1.35 & -1.02 & -1.52 & -1.34 & -0.89 & -1.67 & -1.57 \\
\hline
\end{tabular}

Heteroskedasticity robust standard errors shown in parentheses. * significant at $10 \%$ level; ** significant at 5\%; *** significant at $1 \%$.

${ }^{\mathrm{a}}$ Estimation is by generalized instrumental variables regression after first differencing. IVs: lags of $p$ from $t-2$ to $t-5$.

${ }^{\mathrm{b}}$ Sargan test of overidentifying restrictions with degrees of freedom reported in parentheses

${ }^{\mathrm{c}} \mathrm{m} 1$ and $\mathrm{m} 2$ Arellano and Bond (1991) test for first order and second order autocorrelation. 